\title{
THE INFLUENCE OF COMPATIBILISER ON THE PROPERTIES OF POLYMER COMPOSITES
}

\author{
Mihai GEORGESCU*, Laurenţia ALEXANDRESCU, Maria SÖNMEZ, Mihaela NITUICĂ, Olga NICULESCU, Dana \\ GURĂU
}

INCDTP - Division: Leather and Footwear Research Institute, 93 Ion Minulescu, sector 3, Bucharest, Romania, mihai. georgescu@icpi.com, mihai.georgesku@yahoo.com

Received: 15.02.2017

Accepted: 09.03.2017

https://doi.org/10.24264/Ifj.17.1.7

\section{THE INFLUENCE OF COMPATIBILISER ON THE PROPERTIES OF POLYMER COMPOSITES}

ABSTRACT. Thermoplastic polymers are materials of the future, with special properties, depending on the type of elastomer, the degree of reinforcement, the type of reinforcement material, the functionalization of the reinforcing material, the type of functionalization agent, the elastomer-compatibiliser-reinforcing agent ratio, etc. Polycarbonate (PC) and polyamide (PA) are two elastomers with high hardness, immiscible due to differences in polarity, processing temperature, and solubility. These factors lead to a poor dispersion of PC in the PA matrix and vice versa. Mechanical and physical properties of these polymer blends come not only from the combination of polymeric compounds, but also from the developed morphological forms (interface). Therefore, an additive is required to act as a compatibiliser able to effectively reduce elastomer viscosity. In order to observe the influence of the selected compatibiliser on the properties of polymer composites, the latter were characterized physico-mechanically and morphologically. Thus, compatibilisers chosen for this study were polycaprolactone and polyalkyloxazoline. These compatibilisers, with specific surface and free energy, intervene in polymer-polymer interactions, increasing compatibility, forming polymer-compatibiliser-polymer bonds. Considering these properties formulations of polymercompounds were established (P1-P13) based on polyamide/compatibiliser/polycarbonate/fibreglass. Tested polymer composites contain different percentages of polyamide and polycarbonate $(90,70,50,30,10)$, compatibiliser (caprolactone and oxazoline) $3-7 \%$, and $10-30 \%$ fibreglass.

KEY WORDS: composites, polymers, polyamide, polycarbonate, compatibilisers

\section{INFLUENTA AGENTULUI DE COMPATIBILIZARE ASUPRA CARACTERISTICILOR COMPOZITELOR POLIMERICE}

REZUMAT. Materialele polimerice termoplaste sunt materiale de viitor, având proprietăţi speciale, în funcţie de tipul de elastomeri, gradul de armare, tipul de material de armare, funcţionalizarea materialului de armare, tipul de agent de funcţionalizare, raportul elastomer-agent de compatibilizare-agent de armare etc. Policarbonatul (PC) şi poliamida (PA) sunt doi elastomeri cu duritate mare, nemiscibili datorită diferențelor de polaritate, temperatură de prelucrare şi solubilitate. Aceşti factori conduc la o slabă dispersie a PC în matricea de PA şi invers. Proprietăţile mecanice şi fizice ale acestor amestecuri polimerice nu provin doar de la combinaţia de compuşi polimerici, ci şi de la formele morfologice dezvoltate (interfaţă). Prin urmare, este necesar un aditiv care să acţioneze ca un compatibilizator capabil să reducă în mod eficient viscozitatea elastomerilor. În vederea observării influenţei compatibilizatorului ales asupra proprietăţilor compozitelor polimerice, acestea au fost caracterizate din punct de vedere fizico-mecanic şi morfologic. Astfel, compatibilizatorii aleşi pentru acest studiu au fost policaprolactona şi polialchiloxazolina. Aceşti compatibilizatori, cu suprafaţă specifică şi energie liberă, intervin în interacţiunile polimerpolimer, mărind gradul de compatibilizare, realizând legături de tipul polimer-compatibilizator-polimer. Având în vedere aceste proprietăţi, s-au stabilit recepturi de compounduri polimerice (P1-P13) pe bază de poliamidă/compatibilizator/ policarbonat/fibră de sticlă. Compozitele polimerice testate conţin procente diferite de poliamidă şi policarbonat $(90,70,50,30,10)$, compatibilizator (caprolactonă şi oxazolină) 3-7\% şi fibră de sticlă 10-30\%.

CUVINTE CHEIE: compozite, polimeri, poliamidă, policarbonat, compatibilizatori

\section{L'INFLUENCE DE L'AGENT COMPATIBILISANT SUR LES CARACTÉRISTIQUES DES COMPOSITES POLYMÉRIQUES}

RÉSUMÉ. Les polymères thermoplastiques sont des matériaux d'avenir, ayant des propriétés particulières, en fonction du type d'élastomère, du degré de renforcement, du type de matériau de renforcement, de la fonctionnalisation du matériau de renforcement, du type d'agent de fonctionnalisation, du rapport de l'agent compatibilisant-élastomère-agent de renforcement, etc. Le polycarbonate (PC) et la polyamide (PA) sont deux élastomères avec une dureté élevée, immiscibles à raison de différences dans la polarité, la température de traitement et la solubilité. Ces facteurs conduisent à une faible dispersion de PC dans la matrice de PA et vice versa. Les propriétés physiques et mécaniques de ces mélanges de polymères ne proviennent pas seulement de la combinaison des composés polymères, mais aussi des formes morphologiques développées (interface). Par conséquent, un additif est nécessaire pour agir comme un agent compatibilisant qui peut réduire effectivement la viscosité des élastomères. Afin d'observer l'influence de l'agent compatibilisant choisi sur les propriétés des composites polymère, ceux-ci ont été caractérisés du point de vue physico-mécanique et morphologique. Ainsi, les agents compatibilisants choisis pour cette étude ont été la polycaprolactone et la polyalkyloxazoline. Ceux-ci, avec leur surface spécifique et leur énergie libre, interviennent dans les interactions polymère-polymère, ce qui augmente la compatibilité, en formant des liens de type polymère-compatibilisant-polymère. Compte tenu de ces propriétés on a établi des formulations de composés polymères (P1-P13) à base de polyamide/compatibilisant/polycarbonate/fibre de verre. Les composites polymères testés contiennent différents pourcentages de polyamide et de polycarbonate $(90,70,50,30,10)$, de l'agent compatibilisant (caprolactone et oxazoline) $3-7 \%$ et $10-30 \%$ fibre de verre.

MOTS CLÉS : composites, polymères, polyamide, polycarbonate, agents compatibilisants

\footnotetext{
*Correspondence to: Mihai GEORGESCU, INCDTP-Division Leather and Footwear Research Institute, 93 lon Minulescu, sector 3, Bucharest, mihai.georgescu@icpi.com, mihai.georgesku@yahoo.com
} 


\section{INTRODUCTION}

A wide variety of new multicomponent polymeric materials have been developed in the last two decades. In the field of polymeric materials, leading companies have oriented towards the development of modified polymer structure with superior physical and mechanical properties compared to those of the base constituents taken individually, which offer superior versatility.

Thermoplastic polymeric composites are novelty materials, with special properties, depending on the type of elastomer, degree of reinforcement, the type of reinforcement material, the functionalization of the reinforcing material, the type of functionalization agent, the elastomer-compatibiliser-reinforcing agent ratio etc. These properties offer high use value in fields which require materials with advanced characteristics: dimensional stability, resistance to UV radiation, solvents, aggressive chemical agents [1-7], impact resistance, and possibility of use in a wide range of temperatures etc. Properties result from a set of summed specific characteristics of individual materials, which arise from physical, mechanical and chemical interactions that occur during manufacturing processes that result in a polymer nanostructure.

Grafted copolymers are currently widely used with the role of compatibility agents in blends with other plastic materials and are generally obtained by grafting free radicals in the melt onto the polymer chains. Most commonly used monomers are maleic anhydride, glycidyl methacrylate and acrylic and vinyl monomers containing reactive functionalized groups.

Based on the above, compatibiliser choice for mixed PA/PC requires special attention. Mechanical and physical properties of these polymer blends arise not only from the combination of polymeric compounds, but also from developed morphological forms (interface).

In this paper polyamide (PA) was used as dispersion phase, due to its processing property at high temperatures $\left(200-230^{\circ} \mathrm{C}\right)$, which confers thermal resistance to the composite, and polycarbonate $(\mathrm{PC})$, a polymer with wide industrial application [8, 9] due to its high impact resistance, was used as the dispersed phase. Compatibiliser (polycaprolactone or polyalkyloxazoline) with specific surface and free energy is involved in polymer-polymer interactions, enhancing compatibility degree [10] and creating polymer-compatibiliserpolymer bonds. The interface can also serve as a nucleation center, as a preferential adsorption place and as a space for chemical reactions. The use of such composite systems is required by features such as heat resistance, mechanical strength, resistance to aggressive agents, low weight, processability, etc.

By establishing optimal types and amounts of polycarbonate, polyamide, compatibiliser (polycaprolactone or polyalkyloxazoline), and optimum processing technological parameters, high performance properties can be achieved, such as: impact and thermal resistance.

The formulations were designed to have predetermined physical (hardness, thermal stability, impact resistance), chemical (vapor, aggressive chemical agents resistance), technological (processing by injection/ extrusion, at controlled temperature and pressure, recyclable, optimized processing time, etc.), and fireproof properties.

\section{MATERIALS AND METHODS}

Polycarbonate and polyamide are two very hard elastomers, immiscible due to polarity, processing temperature, and solubility differences. These factors lead to a poor dispersion of PC in the PA matrix and vice-versa. In this situation, an additive is required [11, 12], that can act as a compatibiliser, which can effectively reduce the elastomer's viscosity.

Multiphase polymeric composites need an adequate dispersion and compatibility method. Thus, the employed compatibiliser has to meet three essential requirements:

- To reduce interfacial tensions, thus achieving a fine dispersion;

- To stabilise the thermal and shearing effect morphology in the obtaining process; 
- To make possible the adhesion between phases, in solid state.

In this regard, the role of the additives, such as compatibilisers, was investigated. The compatibilisers are necessary to adjust the mechanical properties or to promote miscibility in complex systems.

Thus, the compatibiliser (polycaprolactone or polyalkyloxazoline) with specific surface and free energy is involved in polymer-polymer interactions, enhancing compatibility degree, creating polymer-compatibiliser-polymer bonds. The interface can also serve as a nucleation center, as a preferential adsorption place and as a space for chemical reactions. The use of such composite systems is required by features such as heat resistance, mechanical strength, resistance to aggressive agents, low weight, processability, etc.

\section{Materials}

In order to achieve hybrid composites with thermal resistance, the following materials were used:
(1) Polyamide - standard PA for injection Sebamid 6 s3c (Basplast),

(2)Polycarbonate - CALIBRETM

polycarbonate resin, density $1.2 \mathrm{~g} / \mathrm{cm}^{3}$ (Trinseo $\mathrm{Gmb}$ ),

(3)Polycaprolactone, $\mathrm{mp}: 60^{\circ} \mathrm{C}$ (lit), density: $1.145 \mathrm{~g} / \mathrm{cm}^{3}$ (Sigma-Aldrich Chemistry, USA).

(4) 2-ethyl-2-oxazoline - Mw-500.000, density: $1.14 \mathrm{~g} / \mathrm{cm}^{3}$ (lit) (Sigma-Aldrich Chemistry, USA).

(5) simple fibreglass - BMC3 $4.5 \mathrm{~mm}$,

(6)(Organosilane-3-Aminopropyl) trimethoxysilane, Mw-179.29 g/mol, bp: 91$92^{\circ} \mathrm{C}$ (lit) (Sigma-Aldrich Chemistry, USA).

Tables 1 and 2 show the multiphase polymeric composite formulations, based on $\mathrm{PA} / \mathrm{PC}$, with two types of compatibiliser (polycaprolactone, polyalkyloxazoline) and reinforced with simple and treated fibreglass. In order to make the comparison between composites possible, the base simple polymers $\mathrm{PA}$, and $\mathrm{PC}$, were shown in the table. The ratio between the components of the polymeric composites is as follows: $90-70 \%$ PA, $10-30 \%$ PC, 3-7\% compatibiliser and $10-30 \%$

Table 1: Formulations of polymer composites based on PA/PC compatibilised with polycaprolactone

\begin{tabular}{|c|c|c|c|c|c|c|c|c|c|c|c|}
\hline Sample & UM & PA & PC & $\mathrm{P}_{1}$ & $P_{2}$ & $P_{3}$ & $\mathrm{P}_{4}$ & $P_{5}$ & $P_{6}$ & $P_{7}$ & $\mathrm{P}_{8}$ \\
\hline Polyamide & $\%$ & 100 & - & 90 & 50 & 70 & 70 & 70 & 70 & 70 & 70 \\
\hline Polycarbonate & $\%$ & - & 100 & 10 & 50 & 30 & 30 & 30 & 30 & 30 & 30 \\
\hline Polycaprolactone & $\%$ & - & - & - & - & - & 3 & 3 & 5 & 5 & 7 \\
\hline Fibreglass (treated) & $\%$ & - & - & - & - & - & - & - & 10 & - & 30 \\
\hline Fibreglass (simple) & $\%$ & - & - & - & - & - & - & 10 & - & 30 & - \\
\hline
\end{tabular}

Table 2: Formulations of polymer composites based on PA/PC compatibilised with polyalkyloxazoline

\begin{tabular}{lcccccc}
\hline \multicolumn{1}{c}{ Sample } & $\mathrm{UM}$ & $\mathrm{P}_{9}$ & $\mathrm{P}_{10}$ & $\mathrm{P}_{11}$ & $\mathrm{P}_{12}$ & $\mathrm{P}_{13}$ \\
\hline Polyamide & $\%$ & 70 & 70 & 70 & 70 & 70 \\
Polycarbonate & $\%$ & 30 & 30 & 30 & 30 & 30 \\
Polyalkyloxazoline & $\%$ & 3 & 3 & 5 & 5 & 7 \\
Fibreglass (treated) & $\%$ & - & - & 10 & - & 30 \\
Fibreglass (simple) & $\%$ & - & 10 & - & 30 & - \\
\hline
\end{tabular}




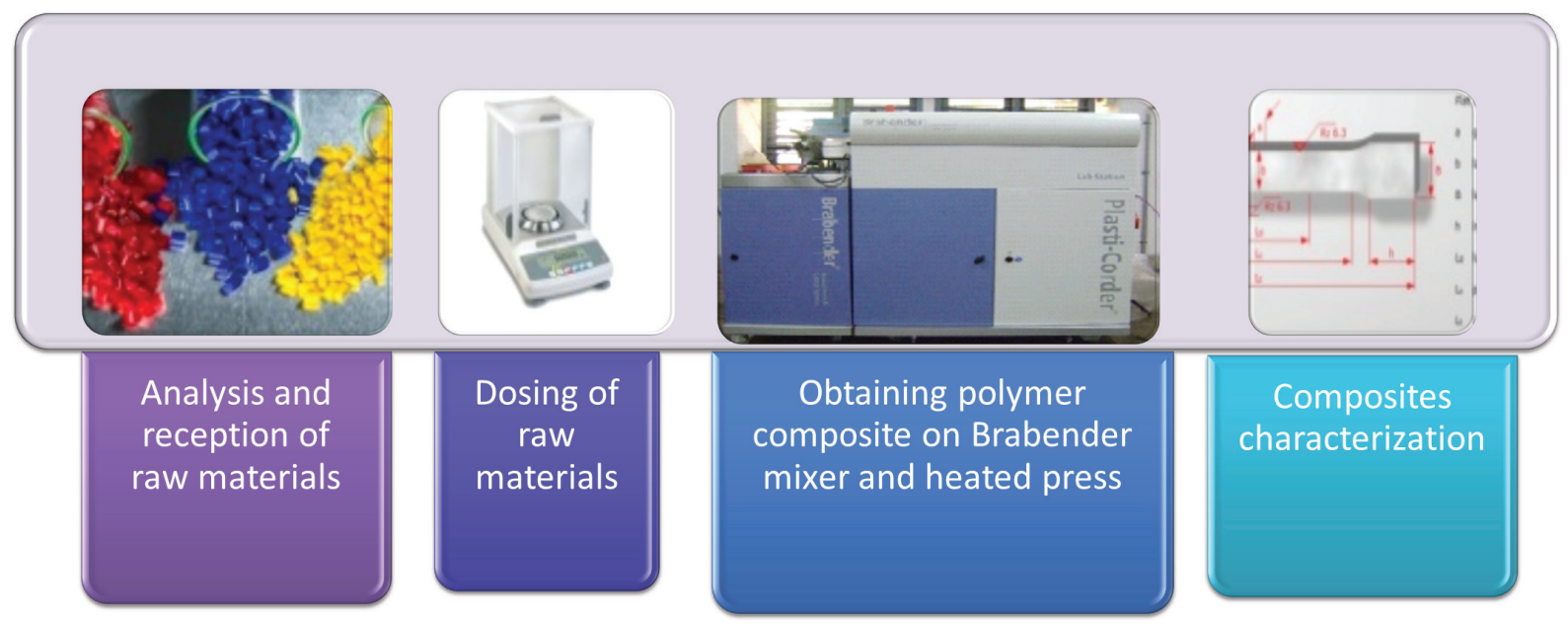

Figure 1. Stages for processing and characterization of the polymeric composites

fibreglass. In order to select the optimal variants, these new materials were characterized according to the rubber and plastic specific standards.

\section{Method}

Regarding obtaining polymeric composites with resistance to high temperature, flame, and impact, a processing technology and formulations for these materials were designed. Thus, the laboratory-scale technological process for polymeric composites based on polyamide and polycarbonate compatibilised with polycaprolactone or polyalkyloxazoline (3$7 \%$ ) and reinforced with fibreglass, is detailed in Figure 1.

The formulations in Tables 1 and 2 were processed in a Brabender mixer, shown in Figure 2. The method for achieving multiphase polymer composites is as follows:

- Weighing the raw materials, according to the formulations;

- Basecomponents, PAandPC, along with the compatibiliser (polycaprolactone or polyalkyloxazoline) are mixed together;

- Setting up the processing parameters through the dedicated software. Temperature was $200^{\circ} \mathrm{C}$ (zone 1) / $200^{\circ} \mathrm{C}$ (zone 2) / $200^{\circ} \mathrm{C}$ (zone 3 );

- The previous obtained mix is introduced in the mixing chamber, and depending on the formulation, the fibreglass is added.
Depending on the formulation, the simple or treated fiberglass was added to the mixture in minute 8 and 13 , respectively, continuing the mixing in the Brabender chamber. The total mixing time is 15 minutes/formulation.

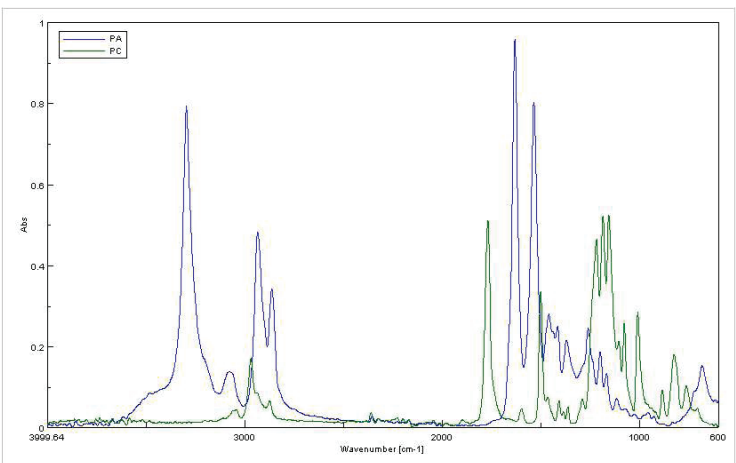

Figure 2. Overlapping IR spectra of PA and PC

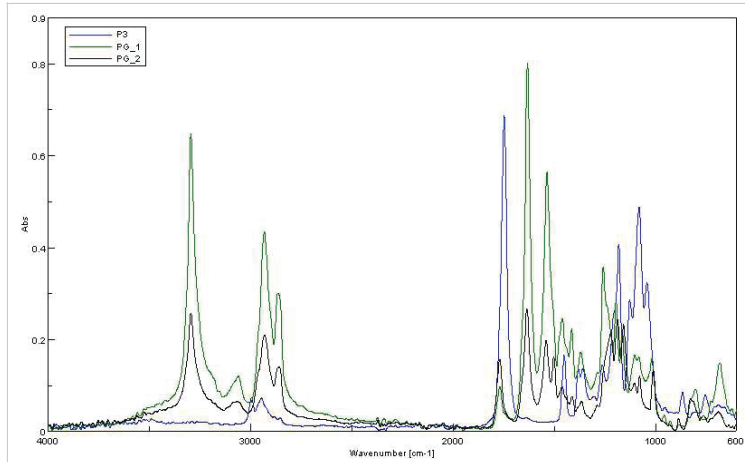

Figure 3. Overlapping IR spectra of PA and PC with various ratios $(P 1, P 2, P 3)$ 


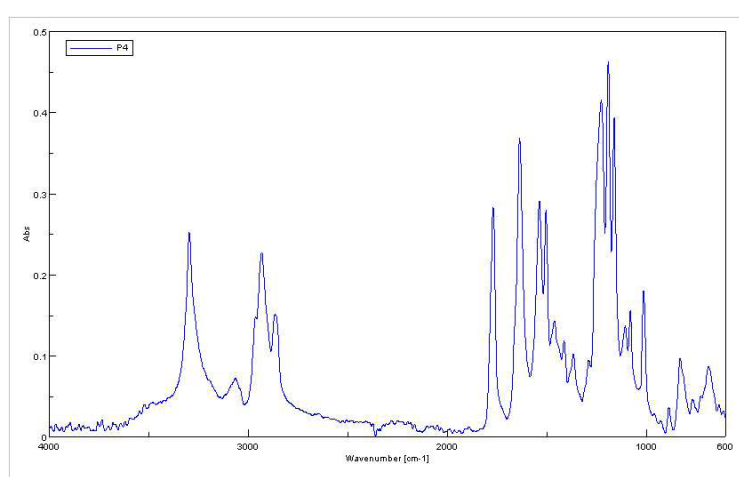

Figure 4. FT-IR spectra for PA/PC/ polycaprolactone (P4)

\section{Characterisation}

\section{FT-IR Spectrometry Characterisation}

IR spectrums represent the radiant energy absorption curve in the IR domain by the sample molecule, depending on the wave length or radiation frequency. The infrared domain of the electromagnetic radiation is between 0.8 and $200 \mu \mathrm{m}$. IR domain for usual organic chemistry is between 2.5 and $25 \mu \mathrm{m}$.

The structural determinations were carried out on an IR molecular absorption spectrometer with double beam, in the range of 4000-600 $\mathrm{cm}^{-1}$, using $4200 \mathrm{FT}$-IR equipped with ATR diamond crystal and sapphire head. The solid state samples were set in the ATR and the equipment recorded the transmittance spectra of the sample and then compared it with the background spectra previously recorded. The recorded spectra of the samples were compared with the pure elastomer spectrum, and with the spectra found in the literature or with the equipment's spectra library.

Overlapping spectra show the presence of $\mathrm{PA}$ and $\mathrm{PC}$ in the polymeric composites in variable percentages, by the intensity of characteristic

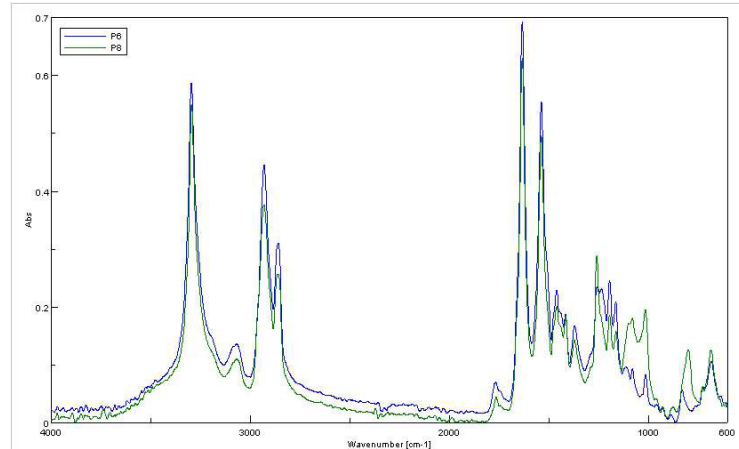

Figure 5. FT-IR spectra for PA/PC w/o compatibilizer (polyalkyloxazoline)

peaks. The presence of polycaprolactone and polyalkyloxazoline compatibilisers in composites is outlined at $1040 \mathrm{~cm}^{-1}$ and $801 \mathrm{~cm}^{-1}$, respectively, in IR spectra. Note that the plastomer (PA and PC) is in excess of the other components, being the main ingredient, thus the fibreglass cannot be distinguished very well in this image, due to its small amount (fibreglass $10 \%$ wt of plastomer).

\section{Physical-Mechanical Characterisation}

The results of the physical-mechanical properties of the samples obtained for the polymer composites based on PA, compatibiliser, PC, and reinforced with fibreglass, are shown in Table 3.

Physical-mechanical characterization was carried out according to standards in force. Following the basic composites characterisation, P3 variant was chosen (70\% PA/30\% PC) to obtain the composites with compatibiliser (3$7 \%)$, simple and treated fibreglass (10-30\%).

\section{Hardness}

Hardness decreases when adding the polycaprolactone or polyalkyloxazoline compatibiliser. When adding simple fibreglass,

Table 3: Physical-mechanical characterisation of the polymeric composites

\begin{tabular}{|c|c|c|c|c|c|c|c|c|c|c|c|c|c|}
\hline Characteristic / Sample & P1 & P2 & P3 & P4 & P5 & P6 & P7 & P8 & P9 & P10 & P11 & $\mathrm{P} 12$ & $\mathrm{P} 13$ \\
\hline $\begin{array}{l}\text { Hardness }{ }^{\circ} \text { Sh D } \\
\text { SR ISO 7619-1:2011 }\end{array}$ & 77 & 78 & 75 & 78 & 80 & 78 & 81 & 79 & 80 & 80 & 81 & 82 & 81 \\
\hline $\begin{array}{l}\text { Tensile strength, } \\
\mathrm{N} / \mathrm{mm}^{2} \text {, (SR ISO } 37: 2012 \text { ) }\end{array}$ & 15 & 19 & 21 & 24 & 27 & 31 & 26 & 38 & 23.8 & 31.7 & 40 & 38.6 & 47 \\
\hline
\end{tabular}




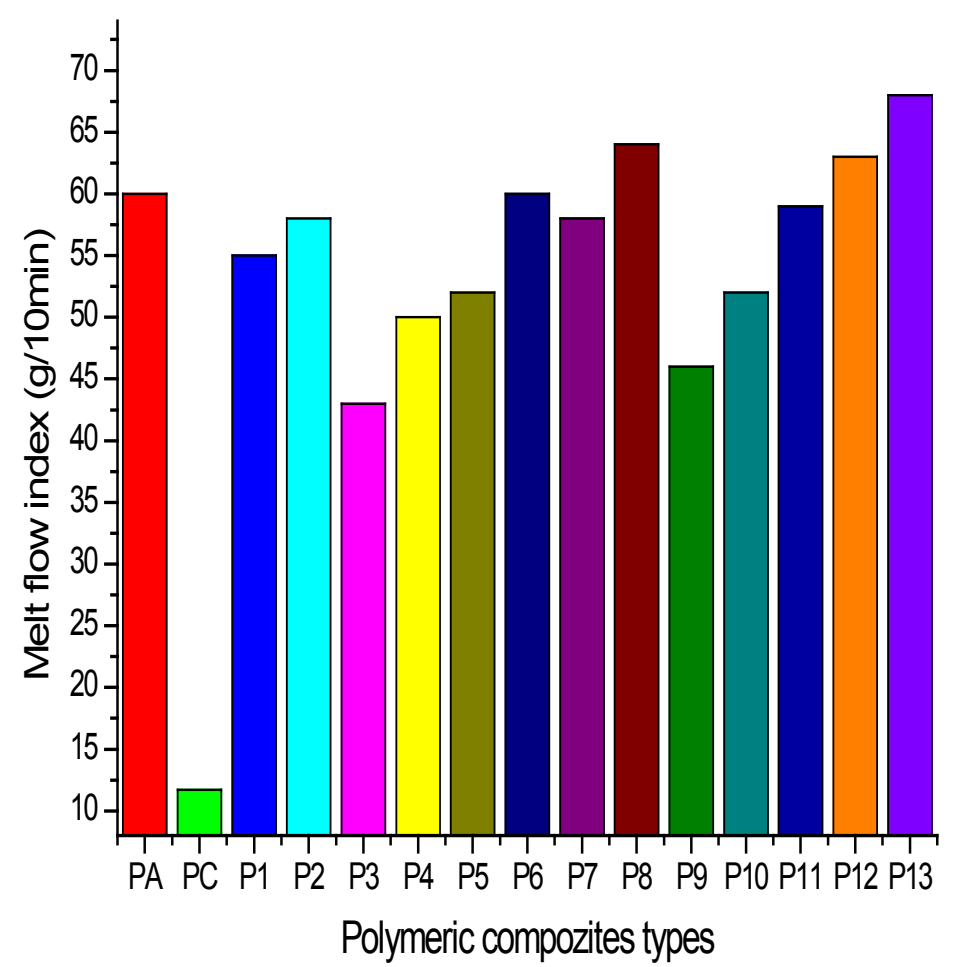

Figure 6. Melt flow index for polymeric composites

hardness increases but using the treated fibreglass instead, the hardness decreases by $1-2^{\circ} \mathrm{Sh}$ D. Thus, for the polymeric composites containing compatibiliser and treated fibreglass this property decreases by $2-3^{\circ} \mathrm{Sh} \mathrm{D}$.

\section{Tensile Strength}

Tensile strength decreases when mixing the plastomers, PA and PC, based on the ratio used between them. The addition of compatibiliser improves the tensile strength compared to P3 composites. With the addition of simple fibreglass tensile strength increases compared to P4 formulations. When using treated fibreglass with the compatibiliser, the value of tensile strength greatly improves. In that sense the composites $\mathrm{P} 8$ and $\mathrm{P} 13$ with $30 \%$ fibreglass show the best values of the tensile strength, of $38 \mathrm{~N} /$ $\mathrm{mm}^{2}$ and $47 \mathrm{~N} / \mathrm{mm}^{2}$, respectively.

Melt Flow Index

The materials used have different characteristics and properties, such as color, density, hardness, different processing temperature, etc. Thus, the melt flow index was determined at the same temperature, of $230^{\circ} \mathrm{C}$, and a pressure force of $5 \mathrm{Kg}$. The values of the melt flow index obtained for the polymeric composites processed in the Brabender mixer are shown in Figure 6.

It is noted that there are considerable differences between the viscosities of the two base polymers (PA and $\mathrm{PC}$ ) which affects the flow of material. Thus, the values obtained for PA were $60 \mathrm{~g} / 10 \mathrm{~min}$ and for $\mathrm{PC}, 11.7 \mathrm{~g} / 10 \mathrm{~min}$. Melt flow index for the obtained composite materials varies widely between these two extremes, due to the base polymer ratio, absence/presence of compatibiliser, absence/presence and the type of fibreglass. Thus, the flow index of composites P1-P3 decreases with increasing percentage of PC. The addition of the polycaprolactone compatibilising agent in a proportion of $5 \%$ increases the melt index value from 43 to $50 \mathrm{~g} / 10 \mathrm{~min}$. While using the polyalkyloxazoline compatibiliser with the same amount of $5 \%$ increases the melt index value to $59 \mathrm{~g} / 10 \mathrm{~min}$.

This characteristic is important in establishing the processing parameters of the polymeric composites into finished products, on the industrial equipment. 


\section{CONCLUSIONS}

After testing the composite samples the following were found:

The compounds based on PA, PC thermoplastic polymers, compatibiliser and treated fibreglass have been selected because they will take advantage of the synergy of the two polymers such as chemical resistance, low water permeability, high temperature, flame, and impact resistance;

The composite sheets were obtained in an electrical heated press, by means of compression, between its plates, at a temperature of $220^{\circ} \mathrm{C}$ and at a pressure of $300 \mathrm{kN}$;

Developed formulations for polymer compounds (P1-P13) based on PA/compatibiliser/ $\mathrm{PC} /$ fibreglass with different amounts of $\mathrm{PA}$ and $P C(90,70,50,30,10)$, compatibiliser (polycaprolactone or polyalkyloxazoline) $5 \%$, and fibreglass $10-30 \%$.

Hardness decreases when adding the compatibiliser, and for the polymeric composites containing compatibiliser and treated fibreglass this property decreases by $2-3^{\circ} \mathrm{Sh} \mathrm{D}$.

Tensile strength decreases when mixing the plastomers, PA and PC, based on the ratio used between them. The addition of compatibiliser improves the tensile strength compared to P3 composites. The composites P8 and P13 with 5\% compatibilisers and $30 \%$ treated fibreglass show the best values of the tensile strength, of $38 \mathrm{~N} /$ $\mathrm{mm}^{2}$ and $47 \mathrm{~N} / \mathrm{mm}^{2}$, respectively.

Melt flow index ranges vary widely for the obtained polymeric composites. Thus, the flow index of composites P1-P3 decreases with increasing percentage of PC. The addition of the polycaprolactone compatibilising agent in a proportion of $5 \%$ increases the melt index value from 43 to $50 \mathrm{~g} / 10 \mathrm{~min}$. The usage of the polyalchyloxazoline compatibiliser with the same amount of $5 \%$, increases the melt index value to $59 \mathrm{~g} / 10 \mathrm{~min}$.

The data presented show that the polyalkyloxazoline compatibilising agent favorably influences physical-mechanical and processing properties compared to polycaprolactone.

\section{Acknowledgements}

This research was financed by ANCSI through NUCLEU Program 2016-2017, project code PN 163401 09: “New Types of Polycarbonate/ Polyamide/Fibreglass Compounds Resistant to Impact, Used in Automotive and Electrical Insulators Industries", contract no. 26N/2016.

\section{REFERENCES}

1. Jones, R.O., Ballone, P.A., A Combined Density Functional and Monte Carlo Study of Polycarbonate, Molecules, 2010, 15, 3680.

2. Kricheldorf, H., Luebbers, D., Polymers of CarbonicAcid.3.ThermotropicPolycarbonates Derived from 4,4-dihydroxybiphenyl and Various Diphenols", Macromolecules, 1990, 23, 2656-2662.

3. Liaw, D.J., Chang, P., Synthesis and Characterization of Aromatic and Brominated Aromatic Polycarbonates by Two-PhaseTransfer-Catalyzed Polycondensation of Bisphenols with Trichloromethyl Chloroformate, J Appl Polym Sci, 1997, 63, 195-204.

4. Liu, Z., Cunha, A.M., Yi, X.S., Bernardo, A.C., Key Properties to Understand the Performance of Polycarbonate Reprocessed by Injection Molding, J Appl Polym Sci, 2000, 77, 13931400.

5. Loewenstein, K.L., The Manufacturing Technology of Continuous Glass Fibers, 3rd revised ed., Elsevier, 1993.

6. Park, J.H., Hyun, J.C., Kim, W.N., Kim, S.R., Ryu, S.C., Extensional and Complex Viscosities of Linear and Branched Polycarbonates, Macromol Res, 2002, 10, 135-139.

7. Pokharkar, V., Sivaram, S., Poly(alkylene carbonate)s by the Carbonate Interchange Reaction of Aliphatic Diols with Dimethyl Carbonate: Synthesis and Characterization, Polymer, 1995, 36, 4851-4854.

8. Lee, J., Song, C., Kim, J.I., Kim, J.H., Preparation of Aromatic Polycarbonates Nanoparticles Using Supercritical Carbon Dioxide, J Nanopart Res, 2002, 4, 53-59. 
9. Sweileh, B.A., Al-Hiari, Y.M., Kailani, M.H., Mohammad, H.A., Synthesis and Characterization of Polycarbonates by Melt Phase Interchange Reactions of Alkylene and Arylene Diacetates with Alkylene and Arylene Diphenyl Dicarbonates, Molecules, 2010, 15, 3661-3682.

10. Sathyanarayana, M.N., Yaseen, M., Role of Promoters in Improving Adhesion of Organic Coatings to a Substrate, Prog Org Coat, 1995, 26, 275-313.

11. Drown, E.K., Moussawi, H.A., Drzal, L., Glass Fiber Sizings and Their Role in Fiber-Matrix Adhesion, Silanes and Other Coupling Agents, Ed. K.L. Mittal, VSP Utrecht, Netherlands, 513-529, 1992.
12. Sautrot, M., Abel, M.-L., Watts, J.F., Powell, J., Incorporation of an Adhesion Promoter in a Structural Adhesive: Aspects of Durability and Interface Chemistry, J Adhesion, 2005, 81, 2, 163-187.

(C) 2017 by the author(s). Published by INCDTPICPI, Bucharest, RO. This is an open access article distributed under the terms and conditions of the Creative Commons Attribution license (http:// creativecommons.org/licenses/by/4.0/). 